\title{
Potential Baggase and Molasses Waste Sugar Factory For Mixed Substrates With Cow Manure In Fermentation Process Methanogenic
}

\author{
Ludfia Windyasmara $^{1}$, Ambar Pertiwiningrum ${ }^{2}$ \\ Faculty of Agriculture, Department of Animal Science, Univet Bantara Sukoharjo \\ Department of Animal Products Technology, Faculty of Animal Science, Universitas Gadjah Mada,
}

ABSTRACT

Article history

Accepted: May 4, 2018 ;

Approved: June 1, 2018

* Corresponding author:

E-mail:

windyasmaraludfia@gmail

.com
This study aims to analyze the potential of the sugar mill waste, namely baggase and molasses as a mixture of cow manure as a substrate in a methanogenic fermentation. This study uses 4 treatment that is P0 as controls (100\% cow manure), later in other treatment using a mixture of cow manure comparison: baggase: molasses, P1 (50:20:30), P2 (50:30:20) and P3 ( 50: 40; 10). Parameters measured were nitrogen, carbon, ratio $\mathrm{C} / \mathrm{N}$ and $\mathrm{pH}$ value. The analyze used in this research is statistic analysis. The results were obtained $\mathrm{P} 3$ which is a mixture of substrate $(50: 40: 10)$ has an average value of the content of nitrogen, carbon, ratio $\mathrm{C} / \mathrm{N}$, and high $\mathrm{pH}$ value is compared to the other treatments. Ratio C / N at P3 of 24.47 closest Ratio C / N ideal for methanogenic fermentation which amounted to 25 . The $\mathrm{pH}$ value of the treatment amounted to 7.05 billion $\mathrm{P} 3$ also meet the standards for process fermentation ranging from 6.6 to 7.6 .

Keywords: Cow manure, Baggase, Molasses, Methanogenic fermentation

\section{INTRODUCTION}

In the processing of sugar cane waste or by product, among other grounds, filter cake and drops. Derived from sugar cane bagasse are ground and used as fuel in the boilers. Filter cake or filter cake is precipitated from the sap gross in the filter in rotary vacuum filter,while the drops are leftover syrup last of the dishes have been separated sugar by crystallization repeatedly so it no longer possible to produce crystals.

Bagasse can also be regarded as a companion product, because bagasse mostly used directly by the sugar factory as a boiler fuel to produce energy purposes of the process. Drops (molasses) as sewage treatment station also includes a companion product for mostly used as industrial raw materials. As a result, not a few sugar mills that have constraints in storage cane baggase and molasses until the milling season later, the tank was not quite as accommodating as drops are not selling well, or allowing an explosion in a storage tank drops with respect to the process conditions or composition.
Every year Indonesia produce waste bagasse or what is often referred to baggase as much as 47 million tons. Potential baggase in Indonesia by the Indonesian Sugar Plantation Research Center (P3GI) in 2012, is quite large with average composition by product of the sugar industry in Indonesia consists of liquid waste $52.9 \%, 11.6 \%$ filter cake, baggase $32.0 \%$, and ash $3.5 \%$. Therefore by product (waste) generated by the sugar mills are quite varied, so that waste is not a problem for the environment, we need a management of such waste. In ways that can be used in sewage treatment that neutralizes the waste so it is not harmful to the environment, and by converting waste into other goods are more valuable.

Indonesia has a good potential in livestock, but has not been fully developed. This is because the majority of farms in Indonesia is a farm that is traditional, including in the processing of waste that has not been touched by technology. Breeders usually accumulates feces before disposing of it or bring it to the fields. The need for proper waste treatment will reduce the impact of pollution on the environment. 
Waste from sugar mills and waste from the farm in the form of animal manure can be a problem in environmental pollution. Therefore, research is needed with the aim of exploring the potential of these wastes to be reused in the processing or handling of biological waste. Thus, the potential of organic matter content in the bagasse and droplets of sugar cane and cow manure can be utilized in applications utilization of waste for renewable energy, one of which is biogas.

\section{MATERIALS AND METHODS}

The raw material used for the sample in this study were drawn from the waste of sugar factory Tasikmadu and dirt cattle were taken from the village of Livestock, Jungke, Karanganyar adjacent.

The equipment used in this study include: (1) agricultural equipment such as: trowel, gloves, plastic bag large size and plastic bag small size.

The experimental design used in this research is the design direction of the control pattern P0 (100\% cow manure), and then successively comparison between cow dung: bagasse: molasses is P1 50: 20: 30; P2 50: 30:
20 and P3 50: 40: 10. Each treatment was repeated two replications.

The analysis done in this study is the proximate analysis. Proximate analysis observed include: nitrogen, carbon, ratio $\mathrm{C} / \mathrm{N}$ and $\mathrm{pH}$ values. Analysis of total carbon was analyzed using methods titrametri (Agriculture Official Chemists Association, 2002). Levels of N-organic obtained by kjeldahl method (American Society of Agronomy and Soil Science Society of America, 1982).

The chemical analysis data was processed using SPSS to obtain statistic data.

\section{RESULT}

In this study, an analysis of the chemical form of the test nitrogen and carbon to determine the chemical content in each material used as the substrate mixture. The results of the chemical analysis of the materials used in mixed substrate is as follows:

Table 1. Results of Chemical Analysis Cow Manure, Baggase and Molasses (\% DM)

Description:

\begin{tabular}{lll}
\hline Type material & Nitrogen & Carbon \\
\hline Cow manure & 2.075 & 31.375 \\
Baggase & 0.034 & 28.735 \\
Molasses & 2.507 & 79.475 \\
\hline
\end{tabular}

DM: dry matter

Three materials are composed of cow manure, baggase and molasses mixed with $100 \%$ control cow manure and using three comparison between the third substrate, that is P1 (50:20:30); P2 (50:30:20) and P3 (50:40:10). The experimental data obtained from nitrogen, carbon, ratio $\mathrm{C} / \mathrm{N}$ and $\mathrm{pH}$ values. The parameters taken are parameters that affect the methanogenic fermentation process. The results of this study are as follows: 
Table 2. Average Test Results Analysis of Nitrogen, Carbon, Ratio C / N and pH value (\% DM)

\begin{tabular}{lcccc}
\hline Treatment & Nitrogen & Carbon & Ratio C / N & $\mathrm{pH}$ \\
\hline P0 & $2.07^{\mathbf{a}}$ & $31.37^{\mathbf{a}}$ & $15.12^{\mathrm{a}}$ & $6.5^{\mathrm{a}}$ \\
P1 & $2.15^{\mathrm{a}}$ & $34.38^{\mathbf{a}}$ & $15.98^{\mathbf{a}}$ & $5.5^{\mathrm{a}}$ \\
P2 & $2.03^{\mathrm{a}}$ & $38.28^{\mathbf{a b}}$ & $18.85^{\mathbf{a}}$ & $6.25^{\mathrm{a}}$ \\
P3 & $2.17^{\mathrm{a}}$ & $53.10^{\mathbf{c}}$ & $24.47^{\mathbf{a b}}$ & $7.05^{\mathrm{a}}$ \\
\hline Mean & $2.10^{\mathbf{a}}$ & $39.28^{\mathbf{a}}$ & $18.60^{\mathbf{a}}$ & $6.32^{\mathbf{a}}$ \\
\hline
\end{tabular}

a,b, c different superscript on the same column shows the difference $(\mathrm{P}<0,05)$

Description:

DM: dry matter

\section{Nitrogen}

Results showed that on average the highest nitrogen content is $\mathrm{P} 3$ which is a mixture of cow manure, baggase and molasses as 50:40:10. Data showed not significant difference with other treatments. According Siallagan (2010) that the nitrogen (N) contained in the organic material will determine the life and activity of microorganisms, as well as affected by Carbon and Ratio $\mathrm{C} / \mathrm{N}$. In the P1 and P3 indicate the value of the nitrogen content of 2.15 and 2.17 higher than P0 (100\% cow manure) and P2. P1 has a relatively high nitrogen levels can be caused by a mixture of molasses in P1 as much as $30 \%$. According Simanjuntak (2009) the nitrogen content in the dry matter of molasses as much as 0.4 to $1.5 \%$, while according to Hugot (1986) nitrogen component in the molasses is composed of protein $(\mathrm{N} x$ 6.26) of 2.5 to 4.5 ; true protein $0.5-1.5$; 0.3-0.5 amino acids and unidentified amounted to 1.5 to 3.0.

\section{Carbon}

Results showed that on average the highest carbon content is P3 which is a mixture of cow feces, baggase and molasses as 50:40: 10 . This may be caused by, the addition baggase with a composition of $40 \%$, causing the carbon content increased significantly compared with other treatments. The content of C-organic is very much needed in the fermentation process. According Musyafa (2004), the content of C-organic can be a source of energy or food for the microbes in the process of fermentation. The highest value is P3 Carbon with carbon content of 53.10 this could be due to the large mixture of cow manure and baggase by $50 \%$ and $40 \%$ there by increasing the carbon content in the mix this P3.

\section{Ratio C/N}

Results showed that the average levels of $\mathrm{C} / \mathrm{N}$ ratio is highest $\mathrm{P} 3$ which is a mixture of cow feces, baggase and molasses as 50:40:10. It is, of course, heavily influenced by two main factors, namely Nitrogen and Carbon.

Below is a graph of Nitrogen, Carbon and Ratio C/N. 


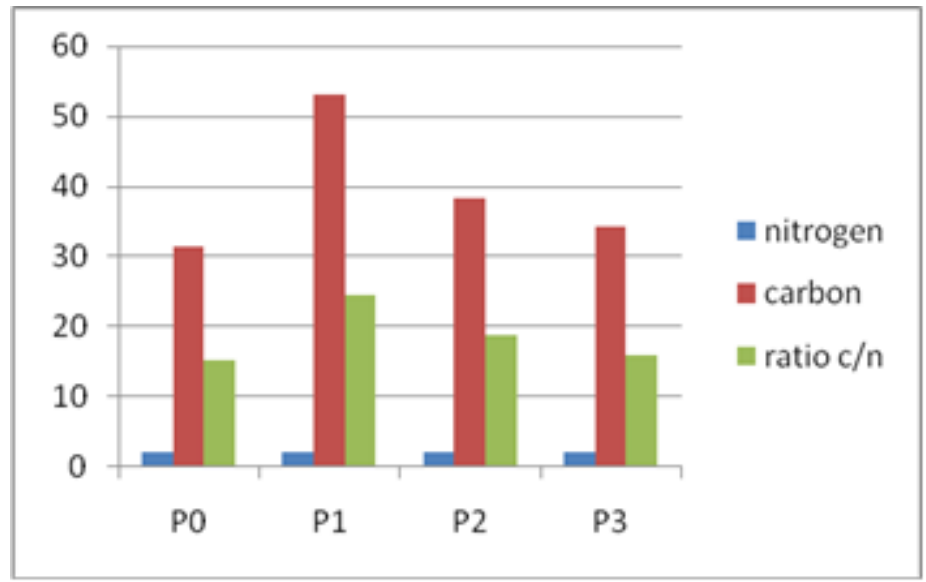

Figure 1. The Graph Relationship Between Carbon, Nitrogen and Ratio C/N

Statement Hartono (2009) that the balance of Carbon (C) and nitrogen $(\mathrm{N})$ contained in the organic matter is very determine the life and activity of microorganisms. The balance of $\mathrm{C} / \mathrm{N}$ that is optimum for the microorganisms perombak is 25-30. Results value ratio $\mathrm{C} / \mathrm{N}$ is the standard approach is the ratio $\mathrm{C} / \mathrm{N}$ at $\mathrm{P} 3$ treatment.

\section{pH value}

Results showed that on average the highest $\mathrm{pH}$ value is $\mathrm{P} 3$ which is a mixture of cow manure, baggase and molasses as 50:40:10, amounting to 7.05. Here is presented a graph the average ph value below.

\section{$\mathrm{pH}$}

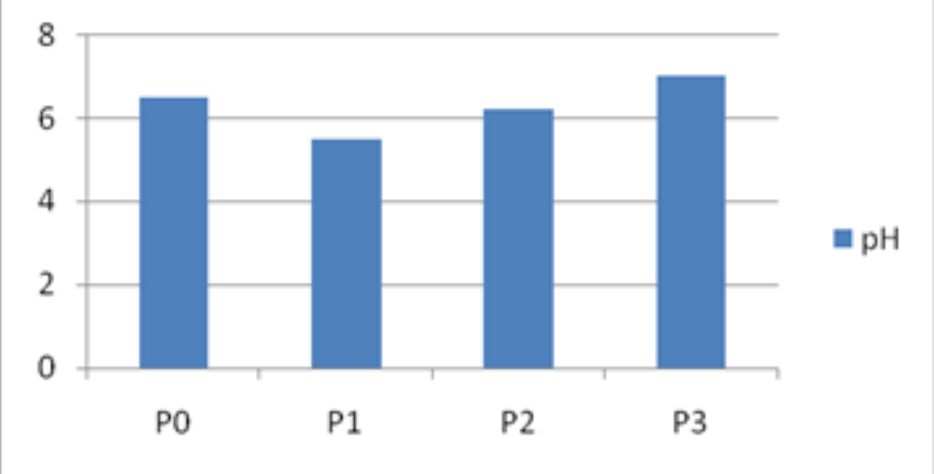

Figure 2 . Graph $\mathrm{pH}$ value

On all 4 treatment there is no significant difference, but according Kaparaju, (2007) anaerobic process should have a $\mathrm{pH}$ of about 6.6 up to 7.6 with the optimum $\mathrm{pH}$ from 7.0 to 7.2 or 7.0 to 7,8 (Shuler and Kargi, 2002). $\mathrm{pH}$ is low at about 6.0 can inhibit hydrolysis acidogenesis and methanogenesis (Lethomaki et al., 2007).

\section{CONCLUSION}

In the treatment of $\mathrm{P} 3$ is the comparison between cow feces: baggase: molasses at 50:40:10 potentially high enough used as the substrate in the fermentation process of methanogenic because it has the average value of the content ratio of $\mathrm{C} / \mathrm{N}$ as big as 24,47 and $\mathrm{pH}$ values 7.05 that correspond to the needs of the organic matter content in the 
e-ISSN: $\underline{2620-9403}$ p-ISSN: $\underline{620-939 X}$

fermentation of methanogenic whose standards have a ratio $\mathrm{C} / \mathrm{N}$ of 25 and a $\mathrm{pH}$ value between 6,6-7.6. Ratio $\mathrm{C} / \mathrm{N}$ and the $\mathrm{pH}$ value is the main parameter in the standard mechanisms of methanogenic fermentation process.

\section{REFERENCES}

American Society of Agronomy and Soil Science Society of America. 1982. Methods of Soil Analysis. $2^{\text {nd }}$ edition, Part 2. In Page et al., (Eds). Chemical and Microbiological Properties. Madison, Wisconsin. USA. P. 1.159

Official Agriculture Chemists Association. 2002. Official Methods of Analysis of AOAC International. IP Volume 2.5-2.37. In Horwitz, W. (Ed). Agricultural Chemicals, contaminants, Drugs. AOAC International, Maryland, USA. $17^{\text {th }}$ edition.

Hartono, R. 2009. Biogas Production from Rice Straw by the addition of Buffalo Dirt. National Seminar on Chemical Engineering Indonesia - SNTKI 2009 ISBN 978-979-98300-1-2. Bandung, 19 to 20 October 2009.

Hugot. E. 1986. Sugar cane Handbook of Engineering. British
Kaparaju, P., I. Buendia, L. Ellegaard and I. Angelidakia. 2007. Effects of Mixing on Metane Production During Thermopilic Anaerobic Digestion of Manure : Labscale and Pilot-scale studies. In: Bioresources technology 2007. Elsevier Ltd.

Lethomaki, A., S. Hutunen, TM Lehtinen and JA Rintala. 2007. Anaerobic Digestion of Grass Silage in Leach Bed Batch Processes for Production Metane. Bioresources Journal 2007.04.072 Technology. Elsevier Ltd

Musyafa. 2004. Soil macrofauna Role in the Process of Litter Decomposition of Acacia mangium Willd. ISSN: 1412-033X. Number January 1,2005. Biodiversity Volume 6, Number 1 Page: 63-65

Sugar Plantation Research Center (P3GI). 2012. Waste Bagasse of Sugar Factories in Indonesia.

Shuler, M. L. and F. Kargi. 2002. Bioproses Engineering. Second ed. Prentice-Hall, Inc., USA.

Siallagan, R. 2010. Pengaruh Waktu Tinggal dan Komposisi Bahan Baku Pada Proses Fermentasi Limbah Cair Industri Tahu Terhadap Produksi Biogas. Fakultas Teknik Program Magister Teknik Kimia Universitas Sumatera Utara Medan.

Simanjuntak, Riswan. 2009. Study of Making Ethanol from sugar waste (molasses). Thesis.USU: Medan. 